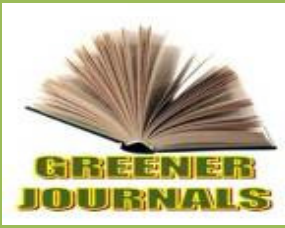

\title{
Effect of Dietary Inclusion of Polyalthia longifolia Leaf Meal as Phytobiotic Compared with Antibiotics on the Nutrient Retention, Immune Response and Serum Biochemistry of Broiler Chicken
}

\author{
Alagbe J.O.
}

Poultry department at Dan-malafia Farms Limited, Ibadan.

\section{ARTICLE INFO}

Article No.: 052217067

DOI: 10.15580/GJAS.2017.3.052217067

Submitted: 22/05/2017

Accepted: 24/05/2017

Published: 30/05/2017

${ }^{*}$ Corresponding Author

Alagbe J.O.

E-mail: demsonfarms@yahoo

.com

Phone: +234 8066671794

Keywords:

broiler chickens, serum

biochemistry, nutrient retention,

immune response
ABSTRACT

A 45-day feeding trial was conducted to evaluate the effect of dietary inclusion of Polyalthia longifolia leaf meal as phytobiotic compared with antibiotics on the nutrient retention, immune response and serum biochemistry of broiler chicks fed corn-soya meal diet. One hundred and fifty day old chick (Ross 308 ) of mixed sex was divided into five groups with three replicates, each of ten birds in a completely randomized design (CRD). Group 1was fed on basal diet without feed additives, group 2 was fed on basal diet supplemented with the antibiotic (Erythromycin) at $25 \mathrm{mg} / \mathrm{kg}$ ), group 3,4 and 5 were fed basal diets supplemented with Polyalthia longifolia leaf meal (PLM) at levels 1.5, 2.5 and 3.5\% respectively. The basal diet was formulated to meet the nutritional requirements of growing birds according to NRC (1994), experimental parameters covered nutrient retention, immune response and some serum biochemical indices. The result revealed that there was a no significant $(P>0.05)$ differences among all treatments in the values of protein retention, fat retention and the serum parameters measured. However, significant influences $(P<0.05)$ were observed for fibre retention and the immune response of the birds to ND and IBD after vaccination. It can be concluded based on the data from the nutrient retention, immune response and those from serum biochemical parameters that PLM could be incorporated up to $3.5 \%$ level in the diet of broiler chickens. 


\section{INTRODUCTION}

Antibiotics are naturally occurring, semi - synthetic and synthetic compounds of antimicrobial activity used in human and veterinary medicine to treat and prevent disease, and for other purposes including growth promotion in food animals. However, there has been a ban on the use of antibiotics as growth promoters in many countries because of its adverse effect on animal, their residues in animal products and the development of antibiotic resistance in bacteria (Lee et al., 2004). Recent studies have been centered on the use of Phytobiotics or medicinal plants in animal nutrition.

Medicinal plants are those plants that are rich in secondary metabolites (steroids, alkaloids, flavonoids, saponins, phenols etc) and arc potential source of drugs. It has a promising future because there are about half million plants around the world, and most of their medical activities have not yet been investigated (Bassam Abdul Rasool Hassan, 2012). According to WHO (1993) around 21,000 plant species have the potential for been used as medicinal plants and are also considered to be very safe as there is no or minimal side effects. Plants such as ginger, garlic, aloe, turmeric, moringa etc are considered to be very important because of their therapeutic value and most recently Polyalthia longifolia is also reported to be rich in ingredients with several beneficial effects for human and animals.

P.longifolia( Sonn) belongs to the family of Annonaceae, is an evergreen plant commonly used as an ornamental street tree due to its effectiveness in combating noise pollution (Kar $S$ et al., 2013). The genus Polyalthia includes about 120 species occurring mainly in Africa, South and South - Eastern Asia, Australia and New Zealand. The therapeutic efficacy of P.longifolia extensively used in Indian system of medicine has been established through modern testing and evaluation in different disease conditions (Katkar, 2010). Reports on the plant has shown that its various parts possess different biological activities Pharmacologic studies on the bark and leaves of this plant show effective antimicrobial activity Faizi et al, 2003), cytotoxic function (Chang et al, 2006; Chen et al, 2006), hypotensive effects (Saleem et al, 2005).

According to Phadnis et al (1998) P.longifoila contains diterpenoids, alkaloids, tannins and mucilage. The seed flour of the plant has been regarded as been under-utilized and with its significant biological and pharmacological activities can be used as additive in diet formulation (lbironke and Emmanuel, 2016). Tannins and saponins function as antioxidants, antimicrobial, antiviral and anti-inflammatory (Adisa et al, 2010).

Sharma et al (2011) reported the antiinflammatory potential of ethanolic and aqueous extracts of Polyalthia longifolia leaf extract in albino wister rats. Preliminary antibacterial activity of various solvent extract of P.longifolia leaves was studied against six different bacteria by disc diffusion method which revealed that all the extract possesses potent antimicrobials against all the test pathogenic organisms (Thenmozhi et al, 2010). The hepatoprotective activity of extracts of $\mathrm{P}$. longifolia was evaluated using albino wistar rats and the result revealed a positive hepatoprotective activity (Tanna et al, 2009).

Several studies have reported on the oral acute toxicity of P.longifolia leaf in mice (Nair et al, 2009) but there is less information on the addition of dried $P$. longifolia leaf meal in the diet of broilers. A timely evaluation of its effects as a phytogenic feed additive in broilers feed will provide useful information relating to the tolerable rate its inclusion in the birds. Therefore this study was conducted to evaluate the effects of various levels of mature Polyalthia longifolia leaf meal as a phytobiotic on the nutrient retention, immune response and serum biochemistry of broiler chicks fed corn-soya meal diet.

\section{MATERIALS AND METHODS}

\section{Site of the experiment}

The experiment was carried out at Dan- malafia Farms, Oyo State, Nigeria. The area is located within the derived savanna zone of Nigeria.

\section{Preparation and processing of experimental diets}

Fresh healthy mature disease free Polyalthia longifolia leaves were harvested from Dan-malafia farms, Ibadan. The leaves were separated, first washed with running tap water and then with distilled water, shade dried without any contamination for 8 days and passed through a hammer mill to produce $P$. longifolia leaf meal (PLM). The test ingredient (PLM) was mixed with other ingredients to form five (5) experimental diets.

Treatment 1: $0 \%$ level inclusion (Negative control treatment)

Treatment 2: basal diet $+25 \mathrm{mg} / \mathrm{kg}$ of Erythromycin (Positive control treatment)

Treatment 3: basal diet $+1.5 \%$ level inclusion of PLM

Treatment 4: basal diet $+2.5 \%$ level inclusion of PLM

Treatment 5 : basal diet $+3.5 \%$ level inclusion of PLM

The diet was formulated to meet the nutrient requirement of broilers according to [NRC, 1994]. Proximate and phytochemical analysis of $P$. longifolia leaf meal was carried out as presented in Table 1 and 2 respectively.

\section{Experimental animals and their management}

A total of 150 one-day-old commercial broiler chicks of mixed sex (Ross 308) were purchased from a local hatchery in Ibadan for use in this study, the birds were 
weighed on arrival and were randomly allotted into five (5) groups with three replicates of 10 birds each in a completely randomized design (CRD). A deep litter poultry house was used for the experiment, prior to the commencement of the trial the house was properly cleaned and disinfected; each pen was equipped with feeders and drinkers to allow unrestricted consumption of feed and water respectively. The initial brooding temperature was $35^{\circ} \mathrm{C}$ in the first week of age which was gradually reduced by $2^{\circ} \mathrm{C}$ per week to $23^{\circ} \mathrm{C}$; vaccines were administered according to the prevailing vaccination schedule in the environment. Feed and water were offered ad-libitum. The light was continuous throughout the experimental period, the performance of the birds in terms of feed intake and mortality were recorded throughout the period of the experiment which lasted for 6 weeks.

\section{Nutrient retention trial}

The nutrient retention trial was carried out on day 21 ; a known quantity of feed was given to each replicate and their faecal output were collected over 72 hour period and subjected to further laboratory analysis.

\section{Immune parameters}

Birds were orally vaccinated against Gumboro virus (on the $11^{\text {th }}$ and $20^{\text {th }}$ days) and Newcastle disease (on the $9^{\text {th }}$ and $16^{\text {th }}$ days). Three (3) birds were randomly selected per replicate to access the antibody response to Newcastle and gumboro virus on the $28^{\text {th }}$ and 42 day of the experiment. Blood samples were collected from the branchial vein of the vaccinated birds and sent to the laboratory for further analysis. Antibody titers against Newcastle and Gumboro viruses were measured using Hemaagglutination Inhibition Test.

\section{Serum analysis}

At day 42, two birds were randomly selected from each replicate for serum analysis, blood samples were collected from the brachial vein into bottles free from anticoagulant. It was centrifuged at 1500 r.p.m for 10 minutes and the serum was separated and analyzed. Serum protein, albumin and globulin were computed according to (Doumas and Briggs, 1972) and cholesterol according to Roschian et al, (1974). Glutamic oxaloacetate transaminase (GOT) and Glutamic phosphate transaminase (GPT) were determined according to Scott (1965).

\section{Chemical analysis}

The proximate components of Polyalthia longifolia leaf meal (PLM) and samples of the five experimental diets were determined by the method of A.O.A.C (1990).

\section{Statistical analysis}

Data collected were subjected to analysis of variance (ANOVA), analysis of variance indicated significant treatment effects and significant means were separated using Duncan's New Multiple Test as described by Steel and Torrie (1980).

Table 1: Proximate composition of P. longifolia leaf meal (PLM)

\begin{tabular}{lc}
\hline Parameter & Dry matter $(\%)$ \\
\hline Crude protein & $10.01 \pm 1.20$ \\
Crude fibre & $19.70 \pm 0.71$ \\
Total Ash & $6.02 \pm 0.05$ \\
Ether extracts & $0.18 \pm 0.07$ \\
Moisture & $7.70 \pm 0.05$ \\
NFE & $59.39 \pm 0.06$ \\
Minerals & Conc. $(\mathrm{mg} / 100 \mathrm{~g})$ \\
Sodium (Na+) & $28.95 \pm 0.34$ \\
Potassium (K+) & $20.66 \pm 1.25$ \\
Calcium (Ca2+) & $77.69 \pm 2.89$ \\
Magnesium (Mg2+) & $25.43 \pm 1.60$ \\
\hline
\end{tabular}


Table 2: Photochemistry of P. longifolia leaf meal (PLM)

\begin{tabular}{lc}
\hline Parameters & Quantity \\
\hline Tannins (ppm) & $3.87 \pm 0.51$ \\
Phenols (ppm) & $0.42 \pm 1.32$ \\
Flavonoids (\%) & $59.1 \pm 2.20$ \\
Alkaloids (\%) & $0.51 \pm 0.13$ \\
Steroids (\%) & $1.19 \pm 1.10$ \\
Saponins (\%) & $1.31 \pm 0.10$ \\
\hline
\end{tabular}

Table 3: Composition of experimental diets of Broilers starter mash (\%): 0-3 weeks

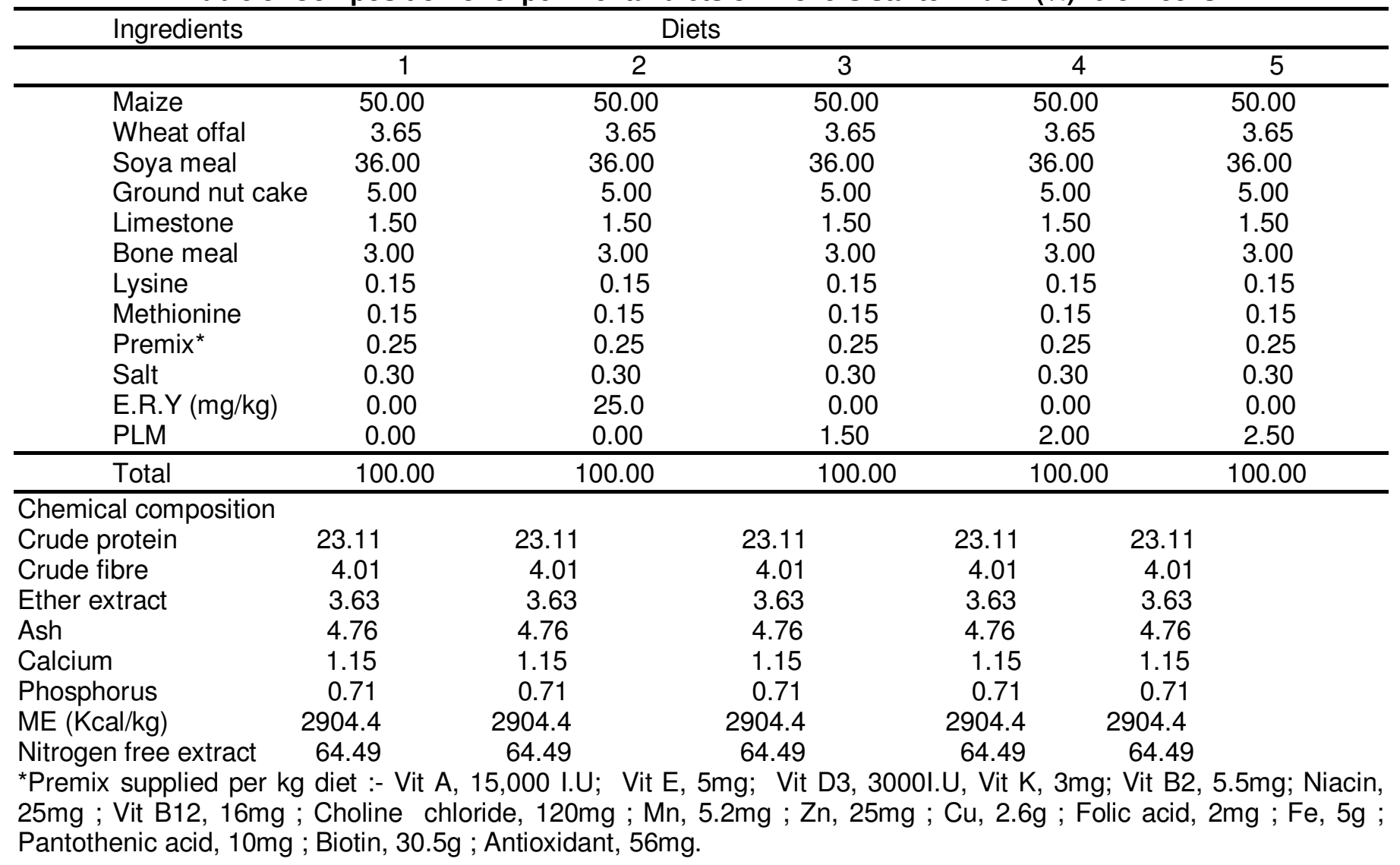


Table 4: Composition of experimental diets of Broilers starter mash (\%): 4-6 weeks

\begin{tabular}{|c|c|c|c|c|c|}
\hline \multirow[t]{2}{*}{ Ingredients } & \multicolumn{3}{|c|}{ Diets } & \multirow[b]{2}{*}{4} & \multirow[b]{2}{*}{5} \\
\hline & 1 & 2 & 3 & & \\
\hline Maize & 55.00 & 55.00 & 55.00 & 55.00 & 55.00 \\
\hline Wheat offal & 8.65 & 8.65 & 8.65 & 8.65 & 8.65 \\
\hline Soya meal & 26.00 & 26.00 & 26.00 & 26.00 & 26.00 \\
\hline Ground nut cake & 5.00 & 5.00 & 5.00 & 5.00 & 5.00 \\
\hline Limestone & 1.50 & 1.50 & 1.50 & 1.50 & 1.50 \\
\hline Bone meal & 3.00 & 3.00 & 3.00 & 3.00 & 3.00 \\
\hline Lysine & 0.15 & 0.15 & 0.15 & 0.15 & 0.15 \\
\hline Methionine & 0.15 & 0.15 & 0.15 & 0.15 & 0.15 \\
\hline Premix* & 0.25 & 0.25 & 0.25 & 0.25 & 0.25 \\
\hline Salt & 0.30 & 0.30 & 0.30 & 0.30 & 0.30 \\
\hline E.R.Y (mg/kg) & 0.00 & 25.0 & 0.00 & 0.00 & 0.00 \\
\hline PLM & 0.00 & 0.00 & 1.50 & 2.00 & 2.50 \\
\hline Total & 100.00 & 100.00 & 100.00 & 100.00 & 100.00 \\
\hline \multicolumn{6}{|l|}{ Chemical composition } \\
\hline Crude protein & 20.81 & 20.81 & 20.81 & 20.81 & 20.81 \\
\hline Crude fibre & 4.31 & 4.31 & 4.31 & 4.31 & 4.31 \\
\hline Ether extract & 3.43 & 3.43 & 3.43 & 3.43 & 3.43 \\
\hline Ash & 5.76 & 5.76 & 5.76 & 5.76 & 5.76 \\
\hline Calcium & 1.20 & 1.20 & 1.20 & 1.20 & 1.20 \\
\hline Phosphorus & 0.56 & 0.56 & 0.56 & 0.56 & 0.56 \\
\hline ME (Kcal/kg) & 3004.1 & 3004.1 & 3004.1 & 3004.1 & 3004.1 \\
\hline Nitrogen free extract & 65.69 & 65.69 & 65.69 & 65.69 & 65.69 \\
\hline
\end{tabular}

*Premix supplied per kg diet :- Vit A, 10,000 I.U; Vit E, 5mg; Vit D3, 3000I.U, Vit K, 3mg; Vit B2, 5.5mg; Niacin, $25 \mathrm{mg}$; Vit B12, 16mg ; Choline chloride, 120mg ; Mn, 5.2mg ; Zn, 25mg ; Cu, $2.6 \mathrm{~g}$; Folic acid, 2mg ; Fe, $5 \mathrm{~g}$; Pantothenic acid, $10 \mathrm{mg}$; Biotin, $30.5 \mathrm{~g}$; Antioxidant, 56mg.

Table 5: Effect of different level of Polyalthia leaf meal (PLM) and antibiotic on the nutrient retention of broilers for 42 days

\begin{tabular}{|c|c|c|c|c|c|c|}
\hline \multirow[t]{2}{*}{ Parameters } & & \multicolumn{5}{|c|}{ Diets } \\
\hline & $1(0 \%)$ & 2 (25mg/kg E.R.Y) & 3 (1.5\% PLM) & 4 (2.5\% PLM) & $5(3.5 \%$ PLM) & SEM \\
\hline Protein retention (\%) & 53.66 & 51.30 & 51.29 & 51.19 & 51.10 & 6.12 \\
\hline Fat retention (\%) & 43.22 & 43.19 & 43.01 & 42.98 & 42.01 & 4.10 \\
\hline Fibre retention (\%) & $75.22 \mathrm{a}$ & $76.67 a$ & $80.78 a$ & $85.71 a$ & $67.99 \mathrm{~b}$ & 4.08 \\
\hline
\end{tabular}

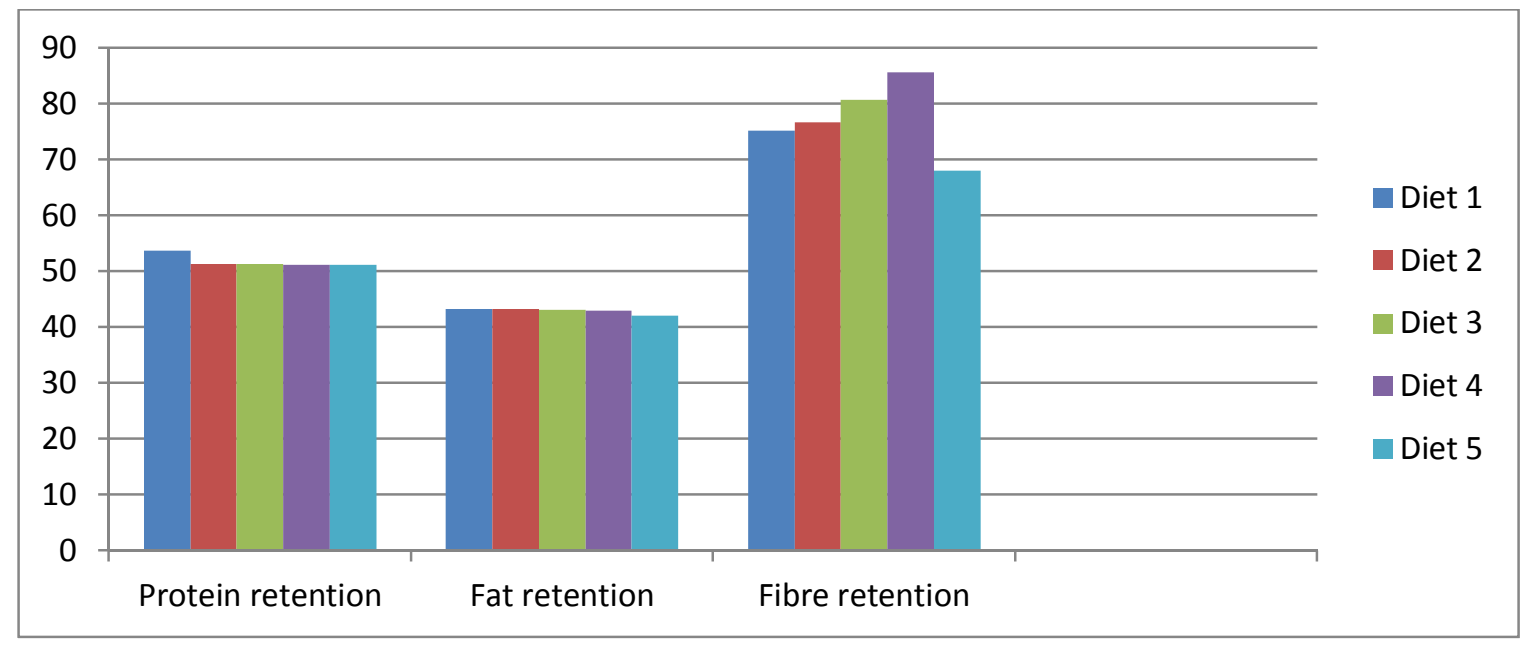

Figure 1: Effect of different level of Polyalthia leaf meal (PLM) and antibiotic (ERY) on the nutrient retention of broilers for 42 days 
Table 6: Effect of different level of Polyalthia leaf meal (PLM) and antibiotic on the serum parameters of broilers

\begin{tabular}{lcccccc}
\hline Parameters & \multicolumn{5}{c}{ Diets } \\
\hline & $1(0 \%)$ & $2(25 \mathrm{mg} / \mathrm{kg} \mathrm{E.R.Y})$ & $3(1.5 \%$ PLM) & $4(2.5 \%$ PLM $)$ & $5(3.5 \%$ PLM $)$ & SEM \\
\hline Albumin (g/dl) & 1.60 & 1.71 & 1.81 & 1.89 & 1.93 & 0.06 \\
Globulin (g/dl) & 1.78 & 1.74 & 1.79 & 1.73 & 1.77 & 0.04 \\
Total protein (g/dl) & 3.38 & 3.45 & 3.60 & 3.62 & 3.70 & 0.16 \\
LDL -Cholesterol (mg/dl) & 15.3 & 16.0 & 15.0 & 16.4 & 16.0 & 1.04 \\
HDL- Cholesterol (mg/dl) & 87.1 & 86.9 & 88.3 & 87.3 & 88.3 & 5.08 \\
Total Cholesterol (mg/dl) & 102.4 & 102.9 & 103.3 & 103.7 & 104.3 & 9.40 \\
GOT (iu/l) & 102.5 & 108.7 & 106.7 & 110.2 & 106.9 & 7.78 \\
GPT (iu/l) & 16.07 & 16.38 & 17.09 & 16.90 & 16.11 & 0.67 \\
\hline
\end{tabular}

$\mathrm{LDL}-$ low density lipoproteins

HDL - High density lipoproteins

GOT- Glutamic Oxaloacetate Transaminase

GPT - Glutamic Phosphate Transaminase

Table 7: Effect of different level of Polyalthia leaf meal (PLM) and antibiotic on the immune response of broilers

\begin{tabular}{|c|c|c|c|c|c|c|}
\hline \multirow[t]{2}{*}{ Parameters } & & \multicolumn{5}{|c|}{ Diets } \\
\hline & $1(0 \%)$ & $2(25 \mathrm{mg} / \mathrm{kg}$ E.R.Y) & 3 (1.5\% PLM) & $4(2.5 \%$ PLM $)$ & $5(3.5 \%$ PLM $)$ & SEM \\
\hline At day 28 & & & & & & \\
\hline Newcastle [N.D] (log2) & $2.78 b$ & $2.99 b$ & $3.89 a$ & $4.09 a$ & $4.41 \mathrm{a}$ & 1.57 \\
\hline Gumboro [IBD] (log2) & $3.07 b$ & $3.11 \mathrm{a}$ & $3.97 a$ & $4.01 \mathrm{a}$ & $4.69 a$ & 0.14 \\
\hline \multicolumn{7}{|l|}{ At day 45} \\
\hline Newcastle [N.D] (log2) & $5.10 \mathrm{~b}$ & $6.13 a$ & $6.68 \mathrm{a}$ & $8.31 \mathrm{a}$ & $8.51 \mathrm{a}$ & 0.78 \\
\hline Gumboro [IBD] (log2) & $3.18 b$ & $4.40 a$ & $4.65 a$ & $5.70 a$ & $6.03 a$ & 0.19 \\
\hline
\end{tabular}

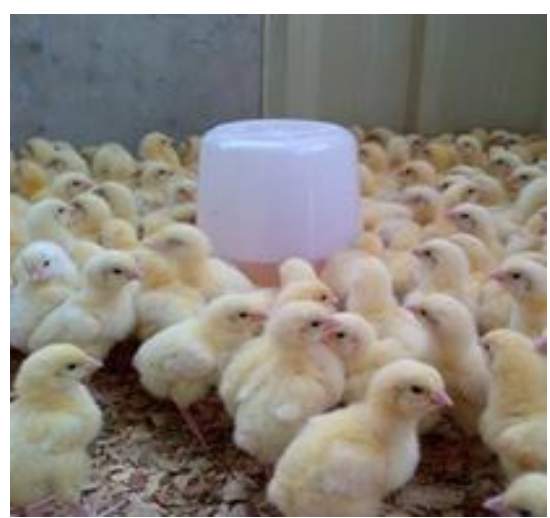

Figure 2: Experimental birds

\section{RESULTS AND DISCUSSION}

The proximate analysis of Polyalthia longifolia leaf meal (PLM) is presented in Table 1. The proximate components are $10.01 \%, 19.70 \%, 6.02 \%, 0.18 \%$, $7.70 \%, 59.39 \%, 28.95 \%, 20.66 \%, 77.69 \%$ and $25.43 \%$ for crude protein, crude fibre, ash, ether extract, moisture, nitrogen free extract, sodium, potassium, calcium and magnesium. This agrees with the report of Ojewuyi et al (2014) and lbironke et al (2016) on the proximate composition of mature $\mathrm{P}$. Iongifolia Sonn. Leaves. PLM contains low crude protein level and it cannot serve as a good protein substitute in a poultry diet; the leaf also contains high level of ash which is a clear indication of an increased mineral content. According to Onwuka (2005), minerals play a large role in biochemical reactions thus allowing efficient metabolic process in the body. The low level of moisture in PLM coupled with the drying process prior to the experiment 
stops the growth of microorganisms, thus increasing the shelf life of the leaves (Awogbemi and Ogunleye, 2009).

The phytochemical analysis of PLM is presented in Table 2. The phytochemical components contains tannins, phenols, flavonoids, alkaloids, steroids and saponins at 3.87ppm, 0.42ppm, 5.91\%, 0.51\%, 1.19\% and $1.31 \%$ respectively. This observation agreed with the views of Anupam et al (2008) on the antibacterial potentiality and phytochemical analysis of mature leaves of Polyalthia longifolia leaves. According to Adisa et al (2010), tannins are known to possess antibacterial and anti viral activity, saponin plays an important role in maintaining blood cholesterol levels (Cheeke, 2000), antimicrobial and anti inflammatory activities (Hassan, 2010 and Soetan et al, 2006).

Table 3 and 4 shows the composition of experimental diet (basal diet). The basal diet was formulated to meet the nutrients requirements of broiler chicks according to NRC (1994).

The effect of different level of Polyalthia longifolia leaf meal (PLM) and antibiotic on the performance of broilers is presented in Table 5. Protein retention values obtained are $53.66 \%, 51.30 \%, 51.29 \%$, $51.19 \%$ and $51.10 \%$

for diets $1,2,3,4$ and 5 respectively while those of fat retention are $43.22 \%, 43.19 \%, 43.01 \%, 42.98 \%$ and $42.01 \%$ for diets 1, 2, 3, 4 and 5 respectively. The values obtained for fibre retention are $75.22 \%, 76.67 \%$, $80.78 \%, 85.71 \%$ and $67.99 \%$ for diets $1,2,3,4$ and 5 . There was no significant $(P>0.05)$ differences in the protein and fat retention for all the diets, fibre retention was influenced by dietary PLM $(P<0.05)$, high fibre retention was obtained in dietary treatment of $3.5 \%$ PLM fed broilers.

The serum biochemical parameters as influenced by the diets are presented in Table 6 . The total protein values obtained are $3.38,3.45,3.60,3.62$ and $3.70 \mathrm{~g} / \mathrm{dl}$ for diets $1,2,3,4$ and 5 respectively while albumin values obtained are $1.60,1.71,1.81,1.89$ and $1.93 \mathrm{~g} / \mathrm{dl}$ for diets $1,2,3,4$ and 5 respectively. The values obtained for globulin are 1.78, 1.74, 1.79, 1.73 and $1.77 \mathrm{~g} / \mathrm{dl}$ for diets $1,2,3,4$ and 5 respectively while the total cholesterol values are 102.4, 102.9, 103.3, 103.7 and $104.3 \mathrm{mg} / \mathrm{dl}$ for diets $1,2,3,4$ and 5 respectively. The values obtained for low density lipoproteins(LDL) are 15.3, 16.0, 15.0, 16.4 and 16.0 $\mathrm{mg} / \mathrm{dl}$ for diets 1, 2, 3, 4 and 5 respectively while high density lipoproteins (HDL) values are 87.1, 86.9, 88.3, 87.3 and 88.3 for diets $1,2,3,4$ and 5 respectively. Glutamic Oxaloacetate Transaminase (GOT) values obtained are 102.5, 108.7, 106.7, 110.2 and $106.9 \mathrm{iu} / \mathrm{l}$ for diets 1,2, 3, 4 and 5 respectively while Glutamic Phosphate Transaminase (GPT) values are 16.07, 16.38, 17.09, 16.90 and $16.11 \mathrm{iu} / \mathrm{l}$ for diets $1,2,3,4$ and 5 respectively.

The total protein values slightly increased from as the level of PLM increased though not at a significant level, which is evidence that PLM contains nutrients that are sufficient to enhance the growth of the birds making it a good test material (Phytobiotics). The albumin, globulin and total protein levels observed in this study were within the ranges for birds reported by Ibrahim Albokhadaim (2012). Cholesterol levels were not significantly $(P>0.05)$ influenced by the different inclusion levels of PLM (Table 7), results from this study showed that the total cholesterol, LDL cholesterol and HDL cholesterol in diet 5 were more than the other treatments, this findings is contrary to the reports of Hossein et al (2015) on the effect of feeding dried sweet orange pulp on the performance and biochemical parameters of broilers.

The GOT values slightly increased as the level of PLM increased but was not significantly $(P>0.05)$ different across the treatment group. Similarly the GPT values slightly increased from diet 1 to 3 after which the values declined though not at a significant level. This observation according to lyayi (1994) suggests that anti nutritional factors in PLM did not seem to have any effect on the above serum parameters.

The immune response parameters as influenced by the diets are presented in Table 7 . On day 28 the Newcastle disease values obtained are 2.78, 2.99, 3.89, 4.09 and $4.41(\log 2)$ for diets $1,2,3,4$ and 5 respectively while those of Gumboro [IBD] are 3.07, $3.11,3.97,4.01$ and $4.69(\log 2)$ for diets $1,2,3,4$ and 5 respectively. The values obtained for Newcastle disease on the 45 day are $5.10,6.13,6.68,8.31$ and 8.51 (log2) for diets 1,2, 3, 4 and 5 respectively while those of Gumboro [IBD] are 3.18, 4.40, 4.65, 5.70 and 6.03 (log2) for diets $1,2,3,4$ and 5 respectively. According to Murthy et al (2005) and Nair et al (2009) P.longifolia leaves are economically important because it has demonstrated significant antibacterial, antifungal, anti viral and antioxidant activities. Pharmacological studies on the bark and leaves of the plants shows display effective antimicrobial activity (Faizi et al, 2003), cytotoxic function (Chang et al, 2006; Chen et al, 2006), hypotensive effects (Saleem et al, 2005).

The values of the antibody titer production for both N.D and IBD were significantly $(P<0.05)$ influenced by different inclusion level of PLM. This is an indication that PLM has demonstrated to be a potent immunomodulatory agent, which is capable of activating the white blood cell to produce more antibodies, thus performing multiple biological activities including antiviral and bacterial properties attributed mainly to their antioxidant and antiradical activity. This observation is in agreement with the reports of Emadi and Kermanshahi (2007) when turmeric powder was included in the diet of broiler chickens fed corn -soya meal diet.

\section{CONCLUSION}

It could therefore concluded that PLM could be efficiently utilized by broilers up to $3.5 \%$ inclusion level without any deleterious effect on the nutrient utilization, immunity and health status of the birds. 


\section{REFERENCES}

Adisa, R. A., Choudhary, E.A., Adenoye, G.A and Olorunsogo, O.O (2010). Hypoglycaemic and biochemical properties of Cnestis ferruginea. African Journal of Traditional Complementary Alternative Medicine 7:185-194.

AOAC, (1990): Association of Official Analytical Chemist Official Method of Analysis $15^{\text {th }}$ Edition Washington, D.C. pages $70-88$.

Awogbemi, O and Ogunleye, I.O (2009). Effects of drying on the qualities of some selected vegetables. ICRISAT Int. Jour. Eng. Tech. 1(5), 1793-8236.

Anupam, Ghosh, Bidnus, Kanti Das., Soroj, Chatterjee and Goutam Chandra (2008). Antibacterial potentiality and phytochemical analysis of mature leaves of $\mathrm{P}$. Iongifolia. The South Pacific Journal of Natural Science, Vol 26, 2008.

Bassam Abdul Rasool Hassan (2012) Medicinal plants, importance and uses. Clinical pharmacy discipline, school of pharmaceutical sciences, University of Sains Malaysia, Rosool Hassan, Pharmceut Anal acta 2012, 3:10.

Chen,C.Y., Chang, F.R., Shih, Y.C., Hsiseh, T. J., Chia Y.C (2006). Cytotoxic constituents of P. longifolia var. pendula : Journal of natural products 2006. 63: 1475-8.

Chang, F.R., Hwang, T.L., Yang, Y.L., C.E Wu. C.C , Issa, H.H., Wu Y.C Planta Medica (2006). 72:1344-1347.

Cheeke, O.N and Nobert, H.O (2000). Serum biochemical parameters in clinically healthy dogs in Ibadan. Tropical Veterinarian 16(3-4), 123-129.

Duncan, DB (1955) Multiple range and multiple $F$ tests. Biometrics, 11:1-42.

Doumas, B.T and Briggs, H.G (1972) Serum Albumen Bromocresol Green Binding Standard Methods. Clinical Chemistry (7) 175-179.

Emadi, E and Kermanshahi (2007) Inhibition of oxidation of human low-density lipoprotein by phenolic substances in red wine. Lancet 341454-45710.1016/01406736(93)90206-V [PubMed] [Cross Ref].

Faizi, S., Azher, R. A., Khan, Tauseef, S and Ahmad, A (2003). New antimicrobial alkaloids from the roots of $P$. Iongifolia var. pendula. Planta Med. 69-350-5.

Hassan, E (2010) Natural polyphenols (vegetable tannins) as drugs: possible modes of action. J. Nat. Prod. 59 20521510.1021/np960040+ [PubMed] [Cross Ref]

Ibrahim Albokhadaim (2012). Haematological and some biochemical values of indigenous chickens in Al-Ahsa, Saudi Arabia during summer season. Asian Journal of Poultry Sciences. 6(4):138-145,2012.

Ibironke Adetolu Ajayi and Emmanuel Nnamdi Ifedi (2016). Proximate analysis and toxicological studies of $P$. longifolia seed flour in dietary formulation of albino rats. American Chemical Science Journal 15(3): 1-12, 2016.

lyayi, E. A (1994). Supplemental effect of low and high cyanide cassava on the performance, nutrient digestibility and serum metabolites of growing pigs. J. Agric. Trop. Subtrop 95:199-205.

Lee K .,Lillehoj, H.S and Siragusa, G.R (2004) Direct feed microbials and their direct impact on the intestinal micro flora and immune system of chickens. Journal of Poultry Science 47:106-114.

Kar S, Maitya J. P., Samal A.C, Santra SC and Jean J S (2013) Bundashuh Journal of deposition and uptake of metals in urban canopy, atmospheric arsenic sequestration. Journal Hazard Mat; 2013.

Katkar, K.V., Suthat, A.C., Chauhan, V.S (2010). Pharmacognosy Review. 2010; 4, 62-68.

Murthy, C ., David, E and Oskar, G.I (2005) Recent advances in animal feed additives such as metabolic, modifiers, antimicrobial agents, probiotics, enzymes and highly available minerals. Institute of Animal Sciences, Nutrition Biology, ETH Zurich, Switzerland Vol 13, No 1: 86-95.

Nair, R., Shukla, V and Chanda, S (2009). Assesment of Polyalthia longifolia var. pendula for hypoglacemic and antihyperglycemic activity. Journal of Clinical and Daigonistic Research. 2009; 3:116-121

NRC, National Research Council (1994). Nutrient Requirements of Poultry. (9 $9^{\text {th }}$ rev. Ed) National Academy Press Washington D.C, USA.

Ojewuyi, O.B., Adebanjo, T.O., Adebanjo, E.O., Balogun, A and Mohammed, A.O (2014). Proximate composition, phytochemical and mineral contents of young and mature P. Iongifolia Sonn. Leaves. Fountain Journal of Natural and Applied Sciences: 3(1):10-19.

Onwuka, G.I (2005). Food analysis and instrumentation; theory and practice Naphthalic Prints, Surulere Lagos Nigeria. 219-230.

Phadnis, G., Richard, S.S and Denise, R. F (1998). Lipponcotts illustrated Reviews Biochemistry $3^{\text {rd }}$ ed., Lippincott Williams and Wilkins, Philadelphia. 335-388.

Roschian, L., Bernat, E and Grubber, W (1974). Enzmtrache Bestmung des gesamcholestrins in serus. clin. Chein. Bio/iem. 12:403-407.

Saleem, R., Ahmed, M., Azeem, M., Khan, R.A and Rasool, N (2005). Hypotensive activity and toxicology of Steel, R. G.D and Torrie, J.H (1986). Principles and procedures of sataistics. A biometrical approach, $2^{\text {nd }}$ edn McGraw-Hill Book Coy. NY. USA.

Steel, R. G.D and Torrie, J.H (1980). Principles and procedures of sataistics. A biometrical approach, $2^{\text {nd }}$ edn McGraw-Hill Book Coy. NY. USA.

Scott, H.M (1965) Measurement of Albino Acid content of fish meal protein by chick growth assay, P.Sc., pp: 395-65.

Soetan, K.O., Akinrinde, A.S and AJibade T.O (2006). Preliminary studies on the haematological parameters of cockerels fed raw and processed guinea corn (Sorghum bicolor) Pg 42-52. Proceedings of $38^{\text {th }}$ Annual Conference of Nigerian Society of Animal Production

Tanna, S., Azher, R. A., Khan, Tauseef, S and Ahmad, A (2009). New antimicrobial saponins from the roots of $P$. longifolia var. pendula. Planta Med. 69-350-5

Thenmozhi, M., Shukla, V and Chanda, S (2010). Assesment of Polyalthia longifolia var. Sonn for antihyperglycemic activity. Journal of Clinical and Diagnostic Research. 2010; 3:116-121.

WHO (1993) Guidelines on the conservation of medicinal plants, IUCN Gland, Switzerland 1993;1:4-6

Cite this Article: Alagbe $\mathrm{JO}$ (2017). Effect of Dietary Inclusion of Polyalthia longifolia Leaf Meal as Phytobiotic Compared with Antibiotics on the Nutrient Retention, Immune Response and Serum Biochemistry of Broiler Chicken. Greener Journal of Agricultural Sciences, 7(3): 074-081, http://doi.org/10.15580/GJAS.2017.3.052217067. 